\title{
INTEGRATION OF YOUNG PEOPLE INTO THE CHURCH BY CHURCH MUSIC
}

\author{
Tiberiu Ardelean*
}

Abstract: Today youth represent tomorrow future of the Church. We live in a world where the phenomenon of the secularization is feeling even more in the life of Christians, that's why the youth of the society in which we live, are confronting with a big feeling of insecurity, emotional, moral and spiritual instability. Every day life and the environment where the youngsters have their activities, doesn't prepare and neither promise a path of wellness for the young generation, who need to find through their own powers the spiritual values and models to keep going and to hope at a consolidation regarding the spiritual life of the youngsters in the Church. The world and the Church are the two poles where the entire creation is supporting on. The world is finding answers at the essential questions in the Church and the Church is getting outside and is preaching the Crucified and Ressurected Truth, into the World. The determinant factor of this synergy between world and Church is obviously the youth. Youth is the element which gives hope to the world and Church for the future.

Keywords: youth, model, faith, Church music, musical workshop.

\section{The role of the music in the Orthodox Church}

Church music is par excellence a border area of liturgical theology with Musicology aims, by its very nature, mediate the two domains, create bridges between them in terms of the art sound and ultimately enriches each area part by loans from the respective acquisitions of complementary concepts.

What is needed in Liturgical Theology musicological works with pronounced character?

The answer is simple: Liturgical Theology segment occupied by the Church Music is one of the pillars of Christian worship, moreover, one of the pillars of the Church's missionary activity. This is

* PhD, Assistant Professor, Faculty of Orthodox Theology "Ilarion V.Felea" at "Aurel Vlaicu" University in Arad 
reflected in the music itself valence through the missionary element that the neophyte both young and experienced believer, located on a higher level or less high on the ladder of Christian perfection, tellingly come into contact; this music, of the church, although the process par excellence in terms of literary sacred, remains dependent on the mode of operation, respectively anatomical physiological rules of musicology.

Any approach of a theme includes highlighting the role and the importance in a particular area. Thus only areas, areas of our lives which remains fully ours are "art and faith". These two phrases cannot exist without the other, because both constitute the most authentic expression of our life.

"The church is a culture unparalleled in history ${ }^{1}$. And gave us words of communion with Himself who is without beginning, Care, humble, descends from the height of our minds, that we would live up to his mind, the one without beginning" .

The passage of time has confirmed and confirms further that the church was made at the highest level an art. Referring to the importance of the art, "experiences of centuries certifies that this important church is not preaching, not ideas, not words, words and words again, but the first thing the church is significance as an art. Because art expresses life, not ideology. A painter with a brush who knows how to play with colors and life experience or what he is good

\footnotetext{
${ }^{1}$ Mircea Buta, The chants of the Church at the Vespers and their intonation essence, in the notes of Trifon Lugojan (Cântările glasurilor bisericeşti la Vecernie şi esenţa lor intonaţională, în notaţiile lui Trifon Lugojan), Arad, Edit. Universităţii „Aurel Vlaicu” Publishing house, 2006.

${ }^{2}$ Father Rafael Noica, in Convorbiri duhovniceşti, by. Ioanichie Bălan, Iaşi, Edit. Mitropoliei Moldovei şi Bucovinei Publishing house, 1995, p.172.
} 
for throwing. A composer who knows his music, certainly is telling us something very special in his life experience or it's useless" ${ }^{3}$.

From this perspective "we should consider the Orthodox civilization and culture, compared with the utilitarian civilization that managed to submit."4

To realize the value and the role of the music in general and orthodoxy in divine worship in particular, we need to look in the light of the negative things. So how would we carry seven praises of the Church without music? Certainly the absence of music would certainly create monotony and fatigue. A wonderful thought to the importance of music ritual of the Church Law - Increase the East is that "with the church music we come into communion with the saints and the righteous of the Christian Church." 5

It is easy to see that in our spiritual ascendance, from the divine services "two thirds of jobs are sung ordinances" And that "by the possibility of rays of the communion beauties (heavenly music) and music arrangements heavenly are the Christian music ... gets all the help from the earth. Gone sensitive beauty of this music, he strives and manages to ascend to heaven beyond the world of beauty". Of course we should not put into question the importance of music in Orthodox Church, even if in some small monastic communities that are exceptions, waivers scales ${ }^{8}$ for some local reason.

Since ancient times it is known the beneficial effect (or harmful) of how musical sounds on humans. Truly, harmony is a

${ }^{3}$ Christos Yannaras, Orthodoxy and the Occident (Ortodoxie şi occident), 1995, Bucureşti, Edit. Bizantină Publishing house, p. 69-70.

${ }^{4}$ Ibidem, p. 70.

5 Gheorghe Şoima, Functions of the liturgical music (Funcţiunile muzicii liturgice), Sibiu, Edit. Revistei Teologice Publishing house, 1945, p. 3.

${ }^{6}$ Arhid. Teacher. Ioan Brie, Chants at the religious services (Cântări la serviciile religioase), Cluj-Napoca, Edit. by the Othodox Achdiocese of Vadului, Feleacului şi Clujului, 1987, p.3.

${ }^{7}$ Gheorghe Şoima, op.cit., p. 29

8 in Greece - Mount Athos there are convents where regular day services are read and not sung. 
reflection of man's inner order. This is a way of appeasement, of union and harmony. Peace is a state of harmony with yourself, which appears when you are grateful to God for everything you have. In ancient times they spoke about harmony of the spheres, standing out a correspondence between musical intervals and distances between celestial bodies known then. Space between the Earth and the Moon, for instance, was identified by Pliny the Elder in the range of tone from a musical range.

The effect of music on the spiritual life of man is discussed typically by St. Basil the Great in his homily addressed to young people, saying: To speak in general and going to where it is needed, purity of soul comprises three things: contempt pleasures fleshly eyes refusal to delight us with nonsensical jokes of buffoons, or bodies that provokes passions and no attention is paid to songs that fool the mind, as the passions result of baseness and humiliation, caused by this kind of music. On the other hand, we must use the music that is good in itself and which in turn leads to good things, namely that the psalmist David, is said to have used it to appease the king's madness.

St. Basil the Great recalls the episode included in "The First Book of Kings", from which we learn that Saul was often troubled by an evil spirit. Then the king's servants brought David, son of Jesse, who, taking the harp and sang so beautifully Saul, that the evil spirit was departed from him. This music, played by David, calm man and brings it to its original state which cannot be other than his relationship with God.

We can say that in the passage cited above, Saint Basil shows the importance of church music, presenting it as a means by which it can clean the soul and can receive healing. Church music spectrum is quite wide, from "chop music and bells" to those songs with specific isons, the psaltic music.

Konstantinos Yannitsiotis remembers a word received from the Father Porphyry Kavsocalivitis on music: "It is good to listen to music. Above all, however, is Byzantine music, because is not disturbing the soul, but it unites him with God and is resting fully. But if you want to 
be very loud, you can hear the profane music, but I think it's better to listen to music that has no words".

Regarding psycho-educational values ${ }^{9}$ and healing is based on the fact that every voice has a Byzantine music, a particular ethos and a specific effect on the human psychic. Each voice born a certain sense of every soul, sometimes exaltation, sometimes melancholy, devotion, sometimes pleading and sometimes sorrow. In this way, healthy man can communicate with God, because prayer is not a mechanical condition but is expressed differently. This variety of feelings is created by music psalms, virtually bringing peace to the soul, and cleaning it.

This shows that the main role of the church music is not an aesthetic one, to adorn religious services, but to renew and restore the middle man in Christ.

And this mediator role in our relationship with Christ acquires music when lived by us as prayer.

Today's musical universe is extremely tender. What you need to know is that not only we must choose according to their "taste" in music, but especially the discerning. When in our power to choose those musical genres which fail harms us spiritually, but we build. It is also wrong to listen to church music only to delight us. First of all, it calls us to own sins, to repent, raises our mind and heart to God. Only they put good start in our healing in Christ.

\section{Orthodox religious music covered by many confessions and multiculturalism.}

It is sad to see that the church music is facing all kinds of obstacles, in terms of its penetration into space and concerns of today's young. In the last two or three centuries, and one increasingly in recent decades, the identity of singing the Orthodox liturgical way was subject to influences from other music, religious or not, that those who cultivate the singing in the Orthodox church, by church singers have in

9 http://www.crestinortodox.ro/liturgica/cantarea/cum-tamaduieste-muzicabisericeasca-142690.html 
contact. Contributed to this particularly new technical means mass and multi - media, which in the circulation of information ever developed, proposed (and propose further) increasingly numerous and various other models music may seem some possible "alternative" to traditional church singing.

Remaining at this generally level can remember the first upgrades in terms of music that took place in other Christian denominations (the Catholic or Protestant), but cannot be overlooked nor many other music of all kinds, which by their cultural impact and fashion, especially on certain social or age areas (and we can think of the impact of mode music on young people) often gives the impression, though usually only fleeting, that "this" or "that music" is the "good", the "to be" or "one who likes" 10 .

For our Church, a vital advantage for the researcher is the good documentation and the historical music, as numerous manuscripts are existing $^{11}$, as well as numerous specialized studies (historical and musicological) already developed over this period ${ }^{12}$ which may allow and formulate the general conclusions necessary.

${ }^{10}$ Vasile Grăjdian, The cultivation of the orthodox chant in multicultual conditions (Cultivarea cântării ortodoxe în condiţii pluriconfesionale şi multiculturale), in rev. "Teologia", nr. 3-4, Arad, 2002, p. 112.

${ }^{11}$ Since the first Romanian musical manuscripts (in notation of Byzantine origin) since the early eighteenth century - v. Filothei Agăi Jipei sin-Romanian psaltichie, Edit. Sebastian Barbu-Bucur in "Sources of Romanian music" vol.VII AD, et transcription document (Vol. I: Catavasier, Bucharest, 1981, volume II: Anastasimatar, Bucharest, 1984; Stihirariul, Bucharest, 1986; vol. IV: Sticherarion-Pentecostarion Buzau, 1992); Anastasimatarul from Cluj-Napoca (ms. 1106), ditto collection ("Sources of Romanian music") vol. VIII, monuments et transcription, Edit. HRIS Trebici-Marin, Bucharest, 1985. Prints of church music from Anastasimatarul Peter Efesiul in Bucharest, May 1820 - v. Titus MOISESCU beginnings pattern Romanian musical notation Byzantine (Peter Efesiul-Macarius Ieromonahul-Anton) in the "Prolegomene Byzantine - Music Byzantine manuscripts and rare books Romanian" Bucharest 1985, p. $82 \mathrm{ff}]$ 12 for example: Sebastian Barbu-Bucur, Byzantine music culture in Romania in the eighteenth and early century XIX and the original contribution of indigenous culture, Bucharest, 1989; Alexis Al. Buzera, Romanian musical culture of century 
We find repeatedly over time, a frequent and forceful repudiation against the novelties that are offered outside the Orthodox Church musical culture. It is what can be seen, for example, the "traditionalists" who opposed in the second half of the nineteenth century introduction choral music invoice harmonic-polyphonic in singing church ${ }^{13}$ However, today, more than a century and a half after these events, we see that choral music has found a place in some Romanian Orthodox Church, although at only mode. Which, from the perspective of historical crystallization does not seem to do justice to the fully radicalism traditionalist line.

Another variant and an attitude refereeing to the introducing of the choral music in the Church it is the "modernists" completely open musical innovations in the Church ${ }^{14}$. The fact already mentioned the successful introduction of harmonic chant seems to give them right in the historical perspective of the present. But in this case, "justice" must be understood very nuanced. Choral singing resounds today in Romanian churches has little to do with the dozens of "Mass choir" composed since the mid-nineteenth century, the vast majority under the influence of Italian opera and German, even if this influence was

Byzantine tradition. nineteenth century, Craiova, 1999; Nicu Moldoveanu, The Romanian church music in the nineteenth century, Part I, the "Voice of the Church" XLI (1982), nr. 1 to 12 January, p. 883-915; Part II, XLII (1983), no. 912, p.594-625; Idem, The Romanian church music in sec. XX, part I, "Romanian Orthodox Church", CIII (1985), nr.7-8, p. 615-636; part II (Creation choral ...) CIV (1986), no.3-4, p.117-139 etc.].

${ }^{13}$ Sebastian Barbu-Bucur, "The angel cried" harmonization of DGKiriac, in „The voice of the Church" XXXIV (1975), nr.7-8, p.764 U.S.; Niphon N. Ploeşteanu, Psaltichie book on church music and linear notes for three voices, Bucharest, 1902, p.76.

${ }^{14}$ Ibidem, p. 764. 
exerted sometimes from the Russian ${ }^{15}$. That might say, in a way quite "orthodox"16.

What has been achieved and penetrated the time was a compromise situation, a situation made through the efforts of several musicians (DG Kiriac or N. Lungu), along with many others who composed a choral music, by using techniques and procedures polyphonic-modal harmonic invoice, with the foundation of the ancient church voices ${ }^{17}$ The solution which was imposed seems to be closest to the attitude of "moderates" harmonic choral singing inception of the Romanian Orthodox Church ${ }^{18}$. Without necessarily an attitude of compromise comfortably in this "moderate" attitude is rather, an attempt to find out what can be good and useful in proposing innovations into the musical culture, to try later an organic framing and as natural like those between realities of the music news confirmed by a venerable tradition, and that, just by virtue of that the tradition cannot be abandoned.

Moving on to other situations in the history of the past centuries, we can notice that some innovations apparent are proposed outside the Orthodox Church are not necessarily "news" in the absolute terms, are actually about retrieving some elements of church traditions, faded with the passage of the time. This is the case in common chant ("the congregation"), which in the first decades of the twentieth century may seem to influence from a Protestant origin ${ }^{19}$, but that was

\footnotetext{
${ }^{15}$ Nicu Moldoveanu, The church music at Romanians in XX century, II part \{oral creation\}, (Muzica bisericească la romani în sec. XX..., partea II \{Creaţia corală...), p. 138-139.

16 Vasile Grăjdian, Growing conditions confessional Orthodox chant and multicultural, rev. "Theology", no. 3-4, Arad, 2002, p. 113.

${ }^{17}$ Nicu Moldoveanu, The church music ..., p. 138.

${ }^{18}$ Nifon N. Ploeșteanu, op.cit., p. 76.

${ }^{19}$ Ştefan Felea, Cântarea în comun, în "Cultura”, XXVII (1938), nr.4-5, p. 37.
} 
obviously a serious theological research soon to be a feature of church chant since the beginnings of Christianity ${ }^{20}$.

Another way to try "what's new" with music into their being is somewhat a "test of time" in the Church and seems to be (was) just to preserve in use together ("opposite" side by side) different musical solutions. Thus, after the introduction of harmonic chant (multiple voices) singing in the traditional monody (the choir) remained to be nurtured further, especially in smaller churches (country) or in monasteries. And also, along with the notation linear western (on the staff), appeared in the horizon chant Orthodox with singing harmonic preserved and the notation psalms, of Byzantine origin, as we see in many hymnals "on both notation" 21 and despite some difficulties in "the practical equivalence of the two systems"22.

Along the same lines of keeping parallel the solutions of different kind of music, it would be reminded how the song is in common, where it was grown more insistent, did not mean the abolition of the role of professional singers (somehow "singer"), and can be even talk about complementary between singer and community, in the sense that the singer is the one that animates and coordinates the joint song ${ }^{23}$.

${ }^{20}$ Pr. Prof. Dr. Ene Branişte, Temeiuri biblice şi tradiţiale pentru cântarea în comun a credincioşilor, în „Studii Teologice”, seria a II-a, VI (1954), nr. 1-2, p. 17-38.

${ }^{21}$ For example, Prof. Nicolae Lungu, Pr. Prof. Grigore Costea, Prof. Ion Croitoru, Anastasimatarul uniformizat - Vecernierul sau cântările Vecerniei de sâmbătă pe cele opt glasuri bisericeşti), Bucharest, Edit. Institutului Biblic şi de Misiune Ortodoxă Publishing house, 1953; Edit. II 1974; Prof. Nicolae Lungu, Pr. Prof. Grigore Costea, Pr. Prof. Ene Branişte, Anastasimatarul uniformizat - Utrenierul (sau cântările Utreniei de Duminică pe cele opt glasuri bisericeşti cu svetilne şi doxologii mari), Bucharest, Edit. Institutului Biblic şi de Misiune Ortodoxă Publishing house, 1954; ed. II 1974.

${ }^{22}$ Ion Popescu-Pasărea, The problem of the transcription of the psaltic music (Problema transcrierii muzicii psaltice), in "Culture", an XXV (1936), nr. 9-11, p. 19.

${ }^{23}$ Ene Branişte, op. cit., p. 33. 
Finally, we must not forget that although the Orthodox Church music is eminently a voice (that are just "scales") in parallel to still kept and has grown even over the millennium into the Christian East and a "seed" of musical instruments by using a very traditional bell and chop $^{24}$.

In another place of the concerns of the church singing in the musicological interest for research invoice byzantinologist, research that also could be considered a "novelty" of the last century ${ }^{25}$, Songs of exile and exploitation of prints and even ancient ${ }^{26}$ manuscripts, reflected in numerous reprints or musical recordings ${ }^{27}$.

${ }^{24}$ Constanța Cristescu, Calls of chop - Romanian repertoire, typology and musical anthology (Chemări de toacă - Repertoriul românesc, monografie, tipologie şi antologie muzicală), Bucureşti, Edit. Academiei Române Publishing house, (1999).

${ }^{25}$ Sebastian Barbu-Bucur, with his alredy cited work (Filothei sin Agăi JipeiPsaltichia românească...), has from a great pallet of researchers, beginning with I.D. Petrescu and has part from his exponents, close to S. Barbu-Bucur, to Gheorghe Ciobanu, G. Panţîru, Titus Moisescu, Nicu Moldoveanu, Alexie Buzera, V. Vasile, Constantin Catrina, Hrisanta Marin, and many others.

${ }^{26}$ Among the many possible examples, in addition to work already cited' of Sebastian Barbu-Bucur, Filothei sin Agăi Jipei-Romanian psaltichie ... and generally the whole series ", Sources of Romanian music", it could remind work paleography ID Petrescu's music (Etudes paleography Byzantine musical, Les Discloses he l'Office canon of Noel, Paris, 1932 paleographer Etudes of Byzantine music, Bucharest, 1967), but some collections of songs and the prior editions spread the uniformity of Romanian Patriarchate at mid-century. twentieth century (Anastasimatarul uniform ...); so are reprinting works of Ion Popescubird, Liturghierul the pew, Edit. Diocese of Arges, 1991, Dimitrie Suceveanu Idiomelar, vol. I.

${ }^{27}$ An example from many others, can be the series of recordings "Electrecord" of the Formation Psalmodia, dirig. Arhid. PhD. Sebastian Barbu-Bucur (MC 001007, STC 001055, STC 001161, STC 001162, STC 001163, STC 001244, STC 001245, STC 001276). 
3. How we integrate young people in the Church of Christ with the song? What we anticipate from them? What alternatives offers the Church?

\section{workshop}

Case study - an analysis of musical works - musical

Lord, my lips ... Of Gavriil Musicescu

Lord, my lips is Part II of Concerto no. 1 G. Musicescu built on the verses of Psalms 23, 50 and 142, Si b major tonality designed in three parts: Allegro, Adagio and Allegro Moderato, preceded by a short introduction.

The second part is inspired by Psalm 50 .

Of all 20 verses of this psalm, Musicescu stopped on one, verse 15: "Lord, open my lips, and my mouth will declare your praise" (Ps. $50,15)$.

Structure form: f. 1 (m. 1-8) - Si b Maj. - Tutti - p f. 2 (m. 9-16) - Do min. - Mi b Maj - Tutti - f p. 3 (m. 17-22) - Do min. - Sol Maj. Solo S-A / T-B - p f. 4 (m. 23 to 28) - Do min. - Tutti - ff. 5 (m. 28-35) - Do min. - Mi b Maj. - Tutti - sf f. 6 (m. 36-48) - Mi b Maj. - Tutti - p

Phrase 1 - (meas.1-8), begins with the entrance (Mi b - tonic tone of this part) followed by a coral harmonic measure to other voices, a shade lower (pp). The debut in parallel octaves (Mi b) bass voice tends to calm the atmosphere created at the end of Part I, and at the same time, to bring a state of prayer and humility.

Phrase 2 - (meas. 9-16), since these measures are shaping the appearance of five different rhythmical formulas that will clothe sound fragment "My mouth". In this phrase first appears in the imitation formula, taking first the bass Sopranos, and the speech writing continuing with the agreement, the bass and soprano have gone contrary, and ends (as the previous sentence) with a cadence V7 - I.

Phrase 3 - (meas. 16-22), is a true example of mastery of contrapuntal technique, Musicescu manages to build an impressive sound fabric. 
Phrase 4 - (meas. 22-28) brings the third formula "My mouth" in tutti, with an expansive character and at the same time containing climax section. The statement represents an modulation in $\mathrm{C}$ minor, the composer is using the same process as the dominant in the beginning of the work.

Phrase 5 - (meas. 28-35), presents the fourth formula fragment of "My mouth", the reason will be picked up alto bass (to measure distance) and then the tenor, followed the soprano to intervene to the extent 33. This phrase is meant to restore the original tonality (Mi b Maj.).

Phrase 6 - (meas. 35-48), the first sentence is related to the onset of the Adagio, bass voice also begins at Mi b and thus comply with an arc, having the time of maximum tension in the phrase 4 . This segment has a conclusive role, ending with a cadence of IV - II2 - I.

\section{The song}

In this creation Musicescu managed to build a speech sound based on a close link between these two elements (text and music), using the Biblical psalm verses. It is a type of song writing accompanied built on dialogues between groups polyphonic voices and imitations.

Harmony is tonal - functional. Cadences accompanying this paper are authentic (V - I); in most cases the composer uses the dominant seventh agreements. The only exception is the moment where the final (meas.46-48), the relationship meet IV - II2 - I polyphony. Besides the polyphonic brief intervention that we encounter there are moments that demonstrate a genuine contrapuntal mastery: meas. 21 of Part II.

Rhythm is simple, based on minim, quarters, eighths. Indication of tempo is adagio.

\section{Dynamics}

The theme song move from one voice to another (meas. 13-21), the voice from the the song must take, in other words do not begin any louder or slower than previous voice finished. The voice that had the song, moving in accompaniment (meas. 28-35), will lower the shade 
with a degree, making a way for the next voice. Only thus can be achieved the melodic continuity.

An important element in working with the choir is the dosage voices and the subtle transitions from choir soloists and vice verse. These acquisitions should give a feeling of continuous dialogue and in no case do not create a rupture in the musical discourse.

The speech sound is built in an arc. All sentences will start from a small nuance, will rise to a climax (which the composer who emphasizes melodic and harmonic even) and will then follow a downward path, preparing the debut of another sentence.

Therefore, I propose such a workshop makes them young people love music and especially the church. Young people should be involved in such exercises. Training these young people must show a huge opening for those activities that involve a lot of time and patience, but certainly the fruit will soon appear. 


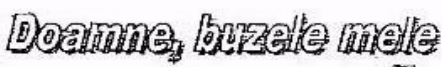

Cancefual $\mathrm{Ne}$ ! Gavril Musicescu
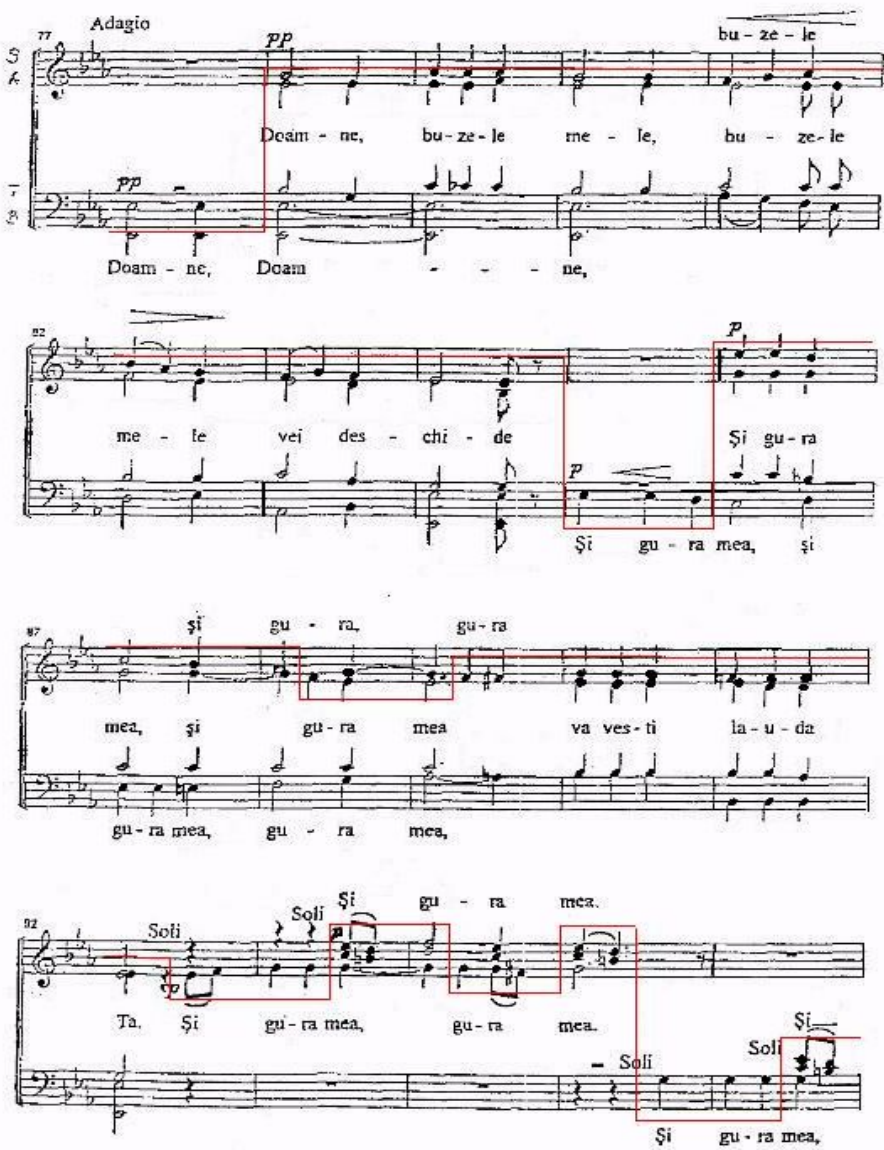

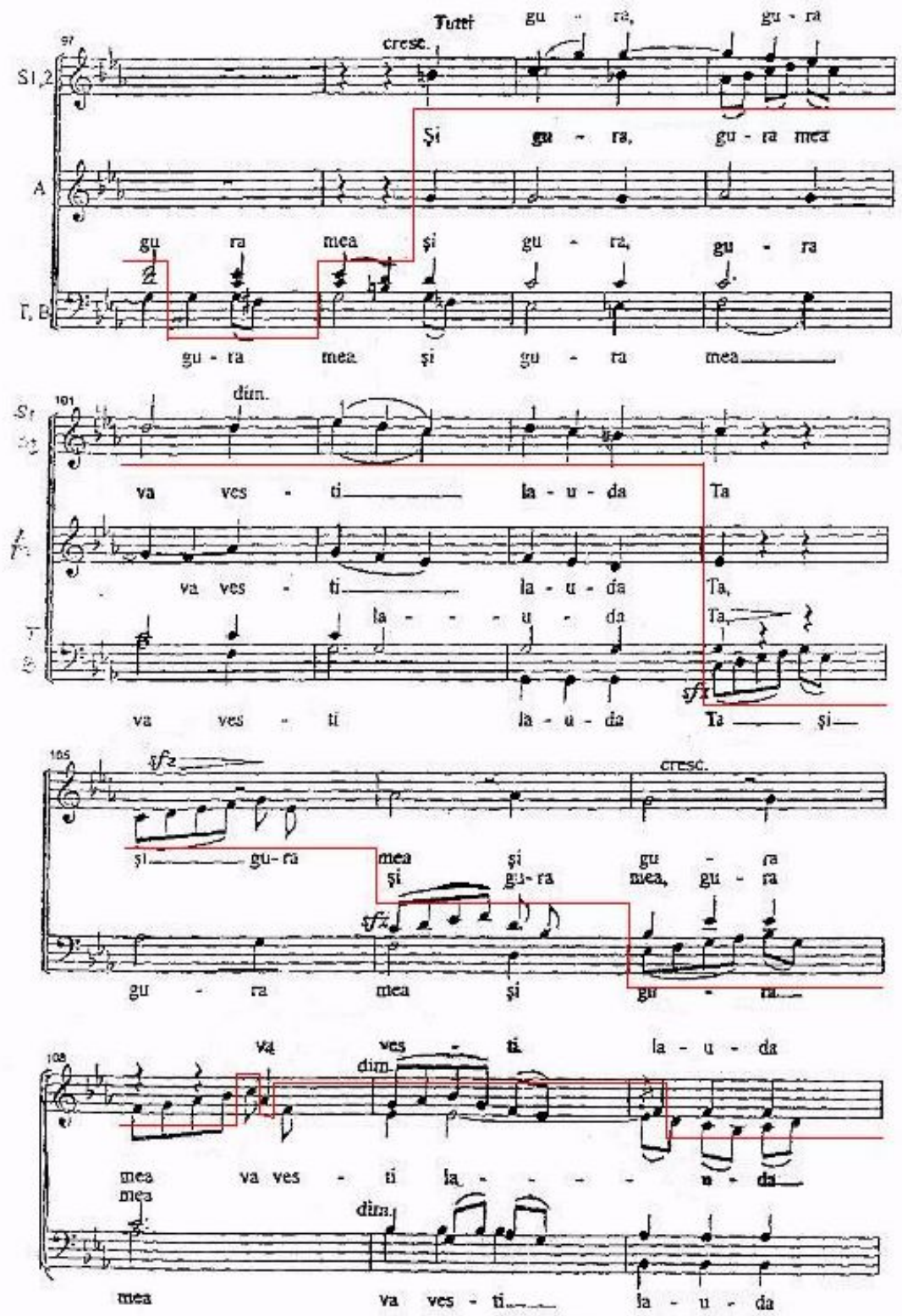

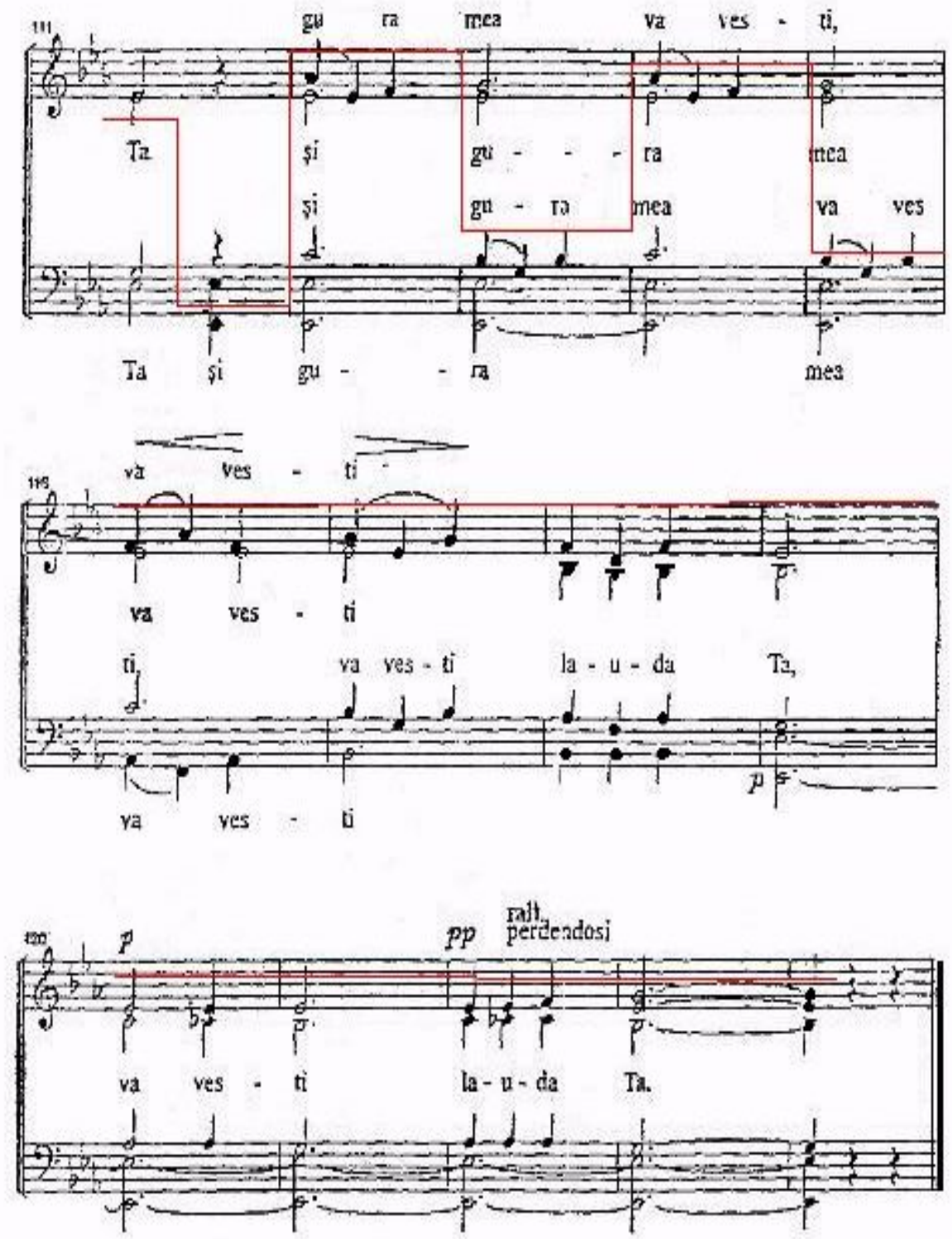


\section{Conclusions}

The world and the church that I mentioned at the beginning, the two pillars of society, are two elements that we can harmonize very difficult, but we have this debt to do it. How? Other elements linking these two mentioned, namely the youth; are exploiting to the maximum.

Young people must make them vibrate in accordance with the teachings of our church-marital law; to discover the beauty of old Byzantium, learned their songs and voices of the ancient church; to expose masses choral harmonies that do nothing but create an environment conducive to the silence of every Orthodox Christian on his journey through the harmonic spectrum, sometimes disharmonious of this world.

The church, in all its forms of organization has a duty to direct the youth towards it, opening them new roads and new horizons in the knowledge of God. Cultural and artistic side of the church has meant to integrate young people into cultural programs in the artistic events organized by the Church. The role of youth in such programs is crucial in the development of this Church. One of the cultural and the artistic palettes which the Church can offer to the young man who is in a permanent search of models is church music, the singing voice of the Church.

\section{Bibliografie}

1. Barbu-Bucur, Sebastian,"The angel cried" harmonization of DGKiriac, in the "voice of the Church" XXXIV (1975), nr.7-8, p.764 U.S.;

2. Branişte, Pr. Prof. Dr. Ene, Temeiuri biblice şi tradiţiale pentru cântarea în comun a credincioşilor, în "Studii Teologice", seria a II-a, VI (1954), nr. $1-2$.

3. Brie, Arhid. Teacher. Ioan, Chants at the religious services (Cântări la serviciile religioase), Cluj-Napoca, Edit. by the Othodox Achdiocese of Vadului, Feleacului şi Clujului, 1987, p. 3.

4. Buta, Mircea, The chants of the Church at the Vespers and their intonation essence, in the notes of Trifon Lugojan (Cântările glasurilor bisericeşti la Vecernie şi esenţa lor intonaţională, în notaţiile lui Trifon Lugojan), Arad, Edit. Universităţii „Aurel Vlaicu” Publishing house, 2006.

5. Cristescu, Constanţa, Calls of chop - Romanian repertoire, typology and musical anthology (Chemări de toacă - Repertoriul românesc, monografie, tipologie şi antologie muzicală), Bucureşti, Edit. Academiei Române Publishing house, 1999.

6. Felea, Ştefan, Cântarea în comun, în "Cultura", XXVII (1938), nr.4-5. 
7. Grăjdian, Vasile, Growing conditions confessional Orthodox chant and multicultural, rev. "Theology", no. 3-4, Arad, 2002.

8. Idem, The cultivation of the orthodox chant in multicultual conditions (Cultivarea cântării ortodoxe in condiţii pluriconfesionale şi multiculturale), in rev. "Teologia", nr. 3-4, Arad, 2002.

9. Lungu, Prof. Nicolae, Costea, Pr. Prof. Grigore, Branişte, Pr. Prof. Ene, Anastasimatarul uniformizat - Utrenierul (sau cântările Utreniei de Duminică pe cele opt glasuri bisericeşti cu svetilne şi doxologii mari), Bucharest, Edit. Institutului Biblic şi de Misiune Ortodoxă Publishing house, 1954.

10. Lungu, Prof. Nicolae, Costea, Pr. Prof. Grigore, Croitoru, Prof. Ion, Anastasimatarul uniformizat - Vecernierul sau cântările Vecerniei de sâmbătă pe cele opt glasuri bisericeşti), Bucharest, Edit. Institutului Biblic şi de Misiune Ortodoxă Publishing house, 1953.

11. Noica, Father Rafael, in Convorbiri duhovniceşti, by. Ioanichie Bălan, Iaşi, Edit. Mitropoliei Moldovei şi Bucovinei Publishing house, 1995.

12. Ploeşteanu, Niphon N., Psaltichie book on church music and linear notes for three voices, Bucharest, 1902.

13. Popescu-Pasărea, Ion, The problem of the transcription of the psaltic music (Problema transcrierii muzicii psaltice), in "Culture", an XXV (1936), nr. 9-11.

14. Şoima, Gheorghe, Functions of the liturgical music (Funcţiunile muzicii liturgice), Sibiu, Edit. Revistei Teologice Publishing house, 1945.

15. Yannaras, Christos, Orthodoxy and the Occident (Ortodoxie şi occident), Edit. Bizantină Publishing house, Bucureşti, 1995.

16. http://www.crestinortodox.ro/liturgica/cantarea/cum-tamaduieste-muzicabisericeasca-142690.html 